\title{
Globalny katolicyzm w polskiej scenografii - ŚDM 2016 w Krakowie
}

\section{Abstract \\ Global Catholicism in Polish Scenography: The 2016 World Youth Day in Kraków}

In July 2016 World Youth Day (WYD) - a global mass event organized every two or three years by the Roman Catholic Church and dedicated to young people - brought thousands of pilgrims to the city of Kraków (Poland) for one week. WYD, which was combined with an official visit by Pope Francis to Poland, is analyzed here as a complex religious-social event that mixes a traditional concept of 'religious pilgrimage' with a popular, mass-culture festival. Basing on ethnographic fieldwork - conducted before, during and after WYD - I will present various and varying attitudes of Kraków's inhabitants towards the event. I will look at local voices but also at the 'local scenography' through an analysis of how the WYD organizers included symbolic capital of Kraków and its 'Christian heritage' within their agenda and shaped the event in religious terms.

Keywords: World Youth Day, Roman Catholic Church, anthropology of religion, religious identity, pilgrimage studies

Słowa kluczowe: Światowe Dni Młodzieży, Kościół rzymskokatolicki, antropologia religii, tożsamość religijna, studia pielgrzymkowe

Ostatni tydzień lipca 2016 roku był w Krakowie czasem niezwykłym. Zdecydowana większość aktywnych zawodowo mieszkańców tej ponad 700-tysięcznej metropolii wyjechała, opuszczając miasto przed zbliżającymi się Światowymi Dniami Młodzieży (ŚDM) i związaną z nimi wizytą papieża Franciszka ${ }^{1}$. Opustoszałe ulice, parki, place, kluby i kawiarnie - które w niedzielę 24 lipca

1 Światowe Dni Młodzieży odbyły się w Krakowie w dniach 25-31 lipca 2016 roku. Wizyta papieża Franciszka rozpoczęła się 27 lipca i trwała aż do zakończenia ŚDM. Nie udało mi się znaleźć wiarygodnych statystyk oddających skalę wyjazdów mieszkańców miasta w omawianym okresie. 
przenikała dojmująca i niespotykana podczas pięknego letniego weekendu cisza już od wczesnych godzin porannych dnia następnego wypełniły się gęstniejącym z godziny na godzinę wielobarwnym, wieloetnicznym i wielojęzycznym tłumem gości - uczestników ŚDM. To spektakularne, masowe, cykliczne wydarzenie religijne, zainicjowane $\mathrm{w}$ połowie lat osiemdziesiątych XX wieku przez papieża Jana Pawła II i organizowane w kilkuletnich odstępach przez Kościół katolicki w różnych miejscach na świecie, latem 2016 roku przyciągnęło do Krakowa kilkaset tysięcy przybyszów pochodzących ze 187 krajów (Bilska-Wodecka, Sołjan, Liro 2017: 204).

Niniejszy artykuł stanowi wstępną prezentację materiałów i omówienie części wyników etnograficznych badań terenowych prowadzonych w Krakowie w okresie poprzedzającym Światowe Dni Młodzieży oraz podczas ich trwania. Zasadniczo badania były sprofilowane pod kątem naukowych założeń projektu HERILIGION (The Heritagization of Religion and the Sacralization of Heritage in Contemporary Europe) i skupiały się na zagadnieniu przestrzeni Krakowa, jej relacji z sacrum oraz wyobrażeniami na temat „chrześcijańskiego dziedzictwa” w kontekście przygotowań i przebiegu Światowych Dni Młodzieży. Dodatkowo skupiłam się na postawach mieszkańców miasta wobec ŚDM oraz na polifonicznym kształcie tego masowego wydarzenia. W związku z tym, że projekt HERILIGION oficjalnie rozpoczynał się we wrześniu 2016 roku, badania przed i podczas ŚDM (lipiec) prowadziłam na własną rękę oraz $\mathrm{w}$ ramach założonej przeze mnie wraz ze studentami z Instytutu Etnologii i Antropologii Kulturowej Uniwersytetu Jagiellońskiego Lotnej Etnograficznej Grupy - LEG ŚDM. Zebrany przez nas materiał stanowi trzon etnograficznych źródeł, na których oparte są poniższe analizy².

W mediach można znaleźć szacunki, które wskazują nawet na 300 tysięcy krakowian (zob. Szpunar, Gurgul 2016).

2 Studenci i doktoranci współtworzący Lotną Etnograficzną Grupę ŚDM brali udział w pracach badawczych na zasadach wolontariatu. Część z nich realizowała własne pomysły badawcze, a niektórzy włączyli się w zaprojektowane przeze mnie badania. W czerwcu przygotowywaliśmy się do intensywnych prac terenowych, które rozpoczęliśmy w pierwszym tygodniu lipca 2016 roku, skupiając się początkowo na mieszkańcach Krakowa oraz przygotowaniach do ŚDM, następnie także na samym wydarzeniu oraz współtworzących je uczestnikach. Niniejszy tekst powstał przede wszystkim w oparciu o materiały etnograficzne zebrane przeze mnie (udokumentowane m.in. w formie notatek terenowych oraz transkrypcji pogłębionych wywiadów), a także Bartosza Arkuszewskiego, Alicję Soćko-Muchę i Dominikę Matejko, którzy przeprowadzili wywiady zgodnie z przygotowanymi przeze mnie wytycznymi (równolegle w czasie trwania ŚDM Dominika Matejko realizowała własne badania wśród pielgrzymów z Ameryki Łacińskiej). Dodatkowo pojedyncze transkrypcje wywiadów do archiwum badań przekazali Kaja Kajder, Paulina Maciejowska, Joanna Sikora i Paweł Witanowski. Spotkania LEG ŚDM odbywające się w czasie intensywnych prac badawczych, wymiana doświadczeń terenowych i prowadzone przez nas „na gorąco” dyskusje stanowiły ważne źródło inspiracji, a także wiedzy, dając etnograficzny ogląd przygotowań, odbioru oraz przebiegu wydarzenia $\mathrm{z}$ różnych perspektyw. Za wszystkie te spotkania dziękuję ich uczestnikom. W ramach projektu HERILIGION w czasie trwania SDM współpracował ze mną fotograf Marcin Wąsik, sporządzając dokumentację fotograficzną oraz filmową. Po zakończeniu SDM prace nad archiwizacją, opracowaniem i analizą materiałów są kontynuowane jako część projektu HERILIGION. Prowadzona 
W tekście staram się ukazać, jak globalne masowe wydarzenie bywa doświadczane oraz kreowane lokalnie. Zwracam uwagę na skomplikowany odbiór ŚDM przez mieszkańców Krakowa, a z drugiej strony wskazuję na aktywizację specyficznego wymiaru przestrzeni miasta (wiązanego z wyobrażeniem „chrześcijańskiego dziedzictwa”) dokonaną przez organizatorów oraz promotorów wydarzenia.

\section{Lokalne głosy}

Kiedy trzydziestokilkuletnia Kasia, mieszkająca w Krakowie w wynajmowanym mieszkaniu, wyjaśniała swoją spontaniczną, podjętą tuż przed Światowymi Dniami Młodzieży decyzję o przyjęciu na noclegi kilku pielgrzymów pochodzących z Azji, z uśmiechem przywołała znane przysłowie: „No, gość w dom, Bóg w dom... nie?”. To nawiązanie do potocznych wyobrażeń na temat tzw. polskiej gościnności mogło zabrzmieć nieco ironicznie w kontekście problemów, jakie do ostatniej chwili mieli organizatorzy ŚDM ze znalezieniem odpowiedniej liczby miejsc noclegowych w niektórych parafiach, mimo iż liczba zarejestrowanych uczestników wydarzenia była finalnie dużo niższa od pierwotnie zakładanej. Nieco ponad dwa tygodnie przed przybyciem pielgrzymów Komitet Organizacyjny ŚDM apelował do mieszkańców Krakowa o goszczenie młodych ludzi i zaoferowanie im noclegów, a w krakowskich kościołach pojawiały się wygłaszane $\mathrm{z}$ ambon zachęty do „otwarcia domów” albo przynajmniej złożenia deklaracji udostępniania łazienek i pryszniców pielgrzymom kwaterowanym w szkołach i namiotach (zob. np. Kościół prosi o pomoc...). Wspomniany przeze mnie exodus - określany przez niektórych naszych rozmówców jako „ucieczka” - sporej części mieszkańców z miasta na okres trwania Światowych Dni Młodzieży, w dużej mierze przełożył się na niewielką ofertę miejsc noclegowych w prywatnych mieszkaniach, zapewne nie tyle podając w wątpliwość oczywistość wyobrażeń na temat „polskiej gościnności”, ile raczej wskazując na skomplikowany stosunek krakowian do wydarzenia. Warto w tym miejscu przyjrzeć się bliżej przyczynom podjętej przez wielu decyzji o opuszczeniu Krakowa oraz rozmaitym opiniom na temat SDM rozpowszechnionym wśród mieszkańców miasta w okresie poprzedzającym wydarzenie. Sądzę, że materiał etnograficzny zebrany w Krakowie w okresie pierwszych trzech tygodni lipca 2016 roku, czyli w czasie najbardziej intensywnych przygotowań

jest również dalsza praca etnograficzna (m.in. wśród mieszkańców Krakowa, którzy przyjmowali w swoich domach pielgrzymów). Niniejszy artykuł został przygotowany jako element prac polskiego zespołu międzynarodowego konsorcjum HERILIGION (liderem konsorcjum jest prof. Oscar Salemink z Uniwesytetu Kopenhaskiego) w ramach programu HERA Uses of the Past (2016-2019). Projekt jest finansowany przez sieć HERA, NCN, AHRC, FCT, DASTI, NWO oraz Komisję Europejską w programie Horyzont 2020 na podstawie umowy nr 649307, a jego polska część, którą kieruję, jest realizowana w Instytucie Etnologii i Antropologii Kulturowej na Wydziale Historycznym Uniwersytetu Jagiellońskiego. 
przed przyjazdem pielgrzymów, dobrze ilustruje panujące nastroje i wskazuje na przynajmniej niektóre formy reakcji i pozycjonowania się mieszkańców wobec zbliżających się Światowych Dni Młodzieży.

Wydaje się, że jednym z najistotniejszych elementów kształtujących postawy sporej części krakowian wobec ŚDM było poczucie braku utożsamiania się z tym wydarzeniem. Wielu ludzi, także tych, którzy ogólnie wyrażali pozytywny stosunek do ŚDM (a nawet planowali wziąć w nich czynny udział), podkreślało, że w ich opinii decyzja o organizacji tak dużej, wielodniowej masowej imprezy w ich mieście została podjęta bez wystarczających konsultacji czy choćby odpowiedniego przygotowania mieszkańców na wiążące się z taką imprezą obciążenia. W rozmowach pojawiały się porównania do pomysłu organizacji w Krakowie zimowych igrzysk olimpijskich, odrzuconego przez większość mieszkańców w referendum w 2014 roku, oraz opowieści o trudnościach, z którymi podczas ŚDM borykały się inne miasta - poprzedni gospodarze wydarzenia. Wspominano m.in. protesty mieszkańców Madrytu (związane z ŚDM w 2011 roku), a w jednej z rozmów ktoś - zapewne mając na myśli Światowe Dni Młodzieży z 2013 roku, których finał zgromadził ponad trzy miliony osób na plaży Copacabana w Rio de Janeiro - stwierdził, że „w którymś tam mieście przecież przyznali, że już ileś lat minęło, a ciągle nie mogą dosprzątać, doczyścić plaży po ŚDM”.

Wiele osób przerażał rozmiar planowanego wydarzenia i pojawiające się w mediach oraz informacjach organizatorów szacunkowe liczby uczestników. W mieście, które na co dzień zamieszkuje mniej niż jeden milion mieszkańców, powtarzana w ciągu całego roku poprzedzającego ŚDM informacja o „spodziewanych 2,5 milionach pielgrzymów” (zob. np. ŚDM 2016. „Kraków będzie przestrzenią..." 2015) wzmacniała przekonanie o niemożności normalnego funkcjonowania w Krakowie podczas trwania wydarzenia ${ }^{3}$. W rozmowach $\mathrm{z}$ etnografami mieszkańcy wskazywali na to, że „Kraków jest zbyt małym miastem na tak dużą imprezę” i że organizacyjnie „nie jest [...] przygotowany na przyjęcie takiej liczby ludzi”. W jednej z rozmów, którą przeprowadziłam dokładnie tydzień przed rozpoczęciem ŚDM, czterdziestoletnia krakowianka - ze względu na swoją pracę i kontakty z miejskimi urzędami dobrze zorientowana w stanie i kosztach przygotowań infrastruktury w miejscach głównych wydarzeń oraz w centrum miasta - wyraziła swój sceptycyzm, przewidując, że:

To będzie spęd, po prostu wielki spęd młodych ludzi. Wydaje mi się, że najbardziej ucierpi tkanka miejska, bo to będzie za dużo [ludzi]... Jest nagonka na festiwale, mówi się o nich, że to „spęd”. A to jest dokładnie to samo! Po prostu zostanie dużo bałaganu po tym wszystkim. A tak naprawdę, czy będzie pozytywny wydźwięk? Ja tego nie widzę...

3 Finalnie na ŚDM 2016 oficjalnie zarejestrowało się 350 tysięcy uczestników, wśród których Polacy stanowili najliczniejszą grupę złożoną z 79 tysięcy osób (Sadłoń 2016: 6). Liczba osób, które przybyły do Krakowa w czasie trwania wydarzenia, była wyższa, gdyż część z nich się nie rejestrowała. Niektórzy przyjechali jedynie na wybrane wydarzenia centralne, spośród których największą popularnością cieszyła się tzw. msza posłania. Według szacunków wzięło w niej udział ponad 2,5 miliona osób (zob. np. Sadłoń, Werner 2016: 4). 
Inna rozmówczyni podkreśliła z kolei, że mimo iż tak duże zgromadzenie będzie „służyć promocji miasta, jak każde takie wydarzenie, na taką światową skalę”, to $\mathrm{z}$ powodu liczby osób i trudnego do opanowania tłumu nie będzie się dało uniknąć zniszczeń, strat i uciążliwości, które zapewne przyniosą „więcej minusów w organizacji tego wydarzenia".

Niewątpliwie wielki rozmach Światowych Dni Młodzieży i ogromna liczba zapowiadanych przybyszów wzmagały wśród mieszkańców Krakowa poczucie, że będzie to impreza zorganizowana w ich własnym mieście, ale raczej „dla innych”, bo „dla nas tu miejsca nie będzie”. Dominujące odczucie przedmiotowego raczej niż podmiotowego potraktowania mieszkańców przez organizatorów działających zarówno w imieniu strony miejskiej, jak i kościelnej niewątpliwie przyczyniło się do słabej wśród krakowian chęci wejścia w rolę „gościnnych gospodarzy”. Część rozmówców wprost mówiła o wyjeździe z miasta jako swego rodzaju narzuconym przymusie, gdyż $\mathrm{w}$ ich zakładach pracy po prostu nakazywano personelowi branie urlopów właśnie w czasie trwania ŚDM, więc dla pracowników był to okres wyjazdów wakacyjnych („Może bym zaplanowała urlop na inny okres, no ale nie miałam wyboru. Tak jest, jak jest [...], no to muszę wyjechać”). Takie rozwiązania wynikały z obaw dotyczących sprawnego działania łączy internetowych i telekomunikacyjnych oraz pozostałej infrastruktury (np. transportu, zaopatrzenia, parkingów). Również wielu krakowian mających swobodniejsze możliwości ustalania terminów kanikuły specjalnie zaplanowało wakacyjny wyjazd na koniec lipca, postrzegając ŚDM przede wszystkim w kategoriach „niedogodności” i „utrudnień”. Niektórzy powoływali się zresztą na radę udzieloną przez prezydenta miasta, który w lutym 2016 roku na antenie Radia Kraków wskazywał na potencjalne olbrzymie utrudnienia dla mieszkańców (np. związane z transportem i przemieszczaniem się po mieście), zachęcał do wzięcia w tym czasie urlopów i „wyjechania na zieloną trawkę" („Podczas ŚDM w Krakowie może być ciężko...” 2016).

Niebagatelny wpływ na decyzje o wyjazdach z miasta wywarł również lęk o bezpieczeństwo, a zwłaszcza pogłoski o możliwych atakach terrorystycznych. W lipcu, przed rozpoczęciem ŚDM, niepokój wśród mieszkańców miasta rósł dosłownie $\mathrm{z}$ dnia na dzień. Ludzie rozmawiali o kwestiach bezpieczeństwa niemal wszędzie: w tramwajach, w kawiarniach, na ulicach i w zakładach pracy czy na spotkaniach towarzyskich. Podczas etnograficznych wywiadów i nieformalnych rozmów na temat ŚDM kwestia obaw o bezpieczeństwo własne, rodzin (zwłaszcza młodych krewnych chcących brać udział w ŚDM), a także przybyszów wypływała najczęściej jako jedna z pierwszych spraw poruszanych spontanicznie przez naszych rozmówców. Już w czerwcu odnotowaliśmy pierwsze warianty opowieści o „terrorystach, którzy tu już są". Typowy schemat narracji opowiada o młodej dziewczynie, która na ulicy znajduje portfel, a w nim pieniądze i dokument $\mathrm{z}$ fotografią. Sprawdza zdjęcie, wśród przechodniów udaje jej się rozpoznać mężczyznę - właściciela dokumentu (który, co charakterystyczne, bywał opisywany jako: „śniady”, „wyglądający arabsko”, „chłopak o egzotycznej urodzie”, w jednej wypo- 
wiedzi pojawił się z kolei „Żyd”). Kiedy podbiega do niego i zwraca mu portfel, ten najpierw jest przestraszony, potem szalenie uradowany. Gdy dziewczyna nie godzi się na przyjęcie znaleźnego, obcokrajowiec łamaną angielszczyzną radzi jej, aby koniecznie opuściła miasto na czas trwania ŚDM, bo „będzie tu bardzo niebezpiecznie", po czym szybko znika $\mathrm{w}$ tłumie. $\mathrm{Z}$ kolei jedna $\mathrm{z}$ krakowianek w rozmowie ze mną przywołała ostrzeżenie, „aby córkę wysłać poza Kraków”, otrzymane od „kogoś, kto pracuje w BOR czy w jakiejś tam agencji” i „opowiada takie rzeczy, że włos na głowie się jeży". Inna osoba wspomniała natomiast o chłodniach należących do zakładów mięsnych pod Krakowem na rozkaz wojska opróżnianych z towarów na czas trwania ŚDM i trzymanych w stanie gotowości („no to już się proszę domyślić, o co chodzi”). Ludzie wspominali inne europejskie miasta - zwłaszcza Paryż (zamach z listopada 2015 roku) i Brukselę (ataki w marcu 2016 roku) - sugerując, że tłumne chrześcijańskie zgromadzenie i spotkanie z papieżem mogą być potencjalnym celem zamachów ${ }^{4}$.

Krążenie mniej czy bardziej miarodajnych pogłosek oraz duża liczba spontanicznych wypowiedzi wskazują, że tematyka bezpieczeństwa, mocno eksponowana w mediach, miała w lipcu 2016 roku bezpośrednie przełożenie na codzienne praktyki i decyzje krakowian związane z funkcjonowaniem w mieście (lub z jego opuszczeniem). Wielu pracowników instytucji i urzędów ulokowanych w Krakowie przeszło obowiązkowe szkolenia antyterrorystyczne, a w funkcjonujących podczas ŚDM zakładach pracy, często jeszcze przed oficjalnym początkiem wydarzenia, wprowadzano nadzwyczajne procedury bezpieczeństwa, związane np. $\mathrm{z}$ przyjmowaniem $\mathrm{w}$ miejscu pracy gości, odbieraniem paczek, ograniczonym

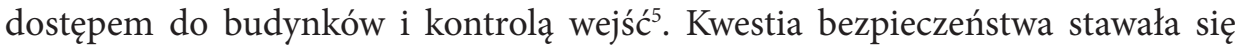
więc czymś realnie odczuwanym, a nie abstrakcyjnym i odległym. Wiadomości o zamachu w Nicei, gdzie 14 lipca rozpędzona ciężarówka wjechała w świętujący i bawiący się tłum ludzi, dodatkowo zwiększyły atmosferę niepokoju. Jedna z moich znajomych w rozmowie telefonicznej, którą przeprowadziłyśmy trzy dni przed rozpoczęciem ŚDM, wyznała:

Uciekłyśmy z Krakowa na wieś. I duży poziom niepokoju odczuwałam. Strasznie. Jakoś wychodząc z domu poczucie, że nie wiadomo, do czego wrócimy [...]. Cieszę się, że moja córka nie chciała w tym [w SDM] brać udziału. Bo nie wiem, jak bym jej to wytłumaczyła... Nie chciałabym jej puścić.

4 Niekiedy w domyśle, niekiedy wprost zamachy były określane jako związane z „terrorystami islamskimi", co interpretacyjnie stanowi istotne odniesienie w kontekście potocznego zestawiania chrześcijaństwa (i katolickich Dni Młodzieży mających być potencjalnym celem ataku) z islamem. Dodatkowo wspomniana powyżej „legenda miejska”, w której pojawia się osoba „wyglądająca arabsko”, ale też postać „Żyda”, dobrze oddaje uruchomienie mechanizmów związanych z kulturowym budowaniem figury „obcego" i strukturalnymi podobieństwami pomiędzy wyobrażeniami Żyda i Araba/żyda i muzułmanina jako „obcych”. Paralele pomiędzy europejskimi dyskursami antymuzułmańskimi i antysemickimi w swoich pracach doskonale uchwyciła Monika Bobako (2017: 163-217).

Takie szkolenia przeprowadzono również na Uniwersytecie Jagiellońskim, a na terenie budynku, w którym pracuję, obowiązywały szczególne środki bezpieczeństwa. 
Tymczasem z chwilą przybycia do miasta uczestników ŚDM atmosfera zagrożenia niemal kompletnie zniknęła, co było wielkim zaskoczeniem, ale też ulgą dla osób, które w mieście pozostały. Obawy - także związane z brakiem internetu, zaopatrzeniem itd. - szybko okazały się wyolbrzymione, a panująca w mieście atmosfera wielkiego ulicznego święta diametralnie zmieniła dyskursy i narracje na temat ŚDM wśród pozostałych w mieście krakowian ${ }^{6}$. Dobrze oddaje to wypowiedź jednej z mieszkanek miasta, zanotowana przez etnografa trzeciego dnia po rozpoczęciu ŚDM:

Teraz mam bardzo pozytywny obraz ŚDM. Wcześniej się obawiałam, rzeczywiście [...]. Nie wiedziałam nawet, czego się spodziewać, zupełnie, jak to w ogóle będzie... A tu się okazuje, że to jest super energia idąca od tych młodych ludzi, więc jest naprawdę fajnie. I można w tym uczestniczyć, mimo że się już nie jest tak do końca młodym...

\section{Postawy i tożsamości}

Zaprezentowane powyżej okoliczności w sposób znaczący uformowały perspektywę, z której mieszkańcy Krakowa patrzyli na ŚDM w pierwszych tygodniach lipca 2016 roku. Stosunkowo niski poziom identyfikacji z wydarzeniem oraz rolą "gospodarzy", którzy mieliby witać i przyjmować przybywających do Krakowa gości, oraz postrzeganie ŚDM w dużej mierze poprzez kategorię negatywnie wartościowanej „masowości” i „imprezy dla innych” rozpatrzyć warto także $\mathrm{w}$ szerszym ujęciu, a mianowicie w kontekście stosunku polskiego społeczeństwa do Kościoła katolickiego, opinii na temat stereotypowego obrazu „Polaka-katolika”, „polskiego” oraz „globalnego” wymiaru katolicyzmu, a także wyobrażeń na temat „religii” kreowanych zarówno przez stronę kościelną, jak i współczesne potoczne dyskursy obecne w ramach polskiego społeczeństwa7

Po pierwsze, należy zauważyć, że w Polsce „masowość” katolickich wydarzeń nie jest bynajmniej czymś niespotykanym czy też społecznie nieakceptowanym. Wręcz przeciwnie, co najmniej od czasu zainicjowanych przez kardynała Stefana Wyszyńskiego obchodów związanych z „odnowieniem ślubów jasnogórskich” (1956) i „tysiącleciem chrztu Polski” (1966) mówić możemy o wykształceniu się

6 Stało się tak pomimo kolejnej informacji z Francji o ataku o charakterze terrorystycznym i zamordowaniu katolickiego księdza w Normandii (26 lipca). Trzeba jednak wskazać, że w Krakowie widoczna była obecność służb ochraniających wydarzenie, a nad miastem praktycznie przez cały czas unosiły się wojskowe helikoptery.

7 W miejscu tym wskazuję na wyobrażenia i potoczne skojarzenia związane ze słowem „religia” - stąd użycie cudzysłowów, które przypominają, iż z punktu widzenia antropologii kulturowej termin „religia” jest kategorią politetyczną i kontekstualną. Funkcjonuje w kulturowych dyskursach, tworząc je oraz odbijając konkretne historyczne uwarunkowania, o czym m.in. pisał niedawno Michael Lambek (2013). 
szczególnej „masowej” formy celebrowania katolicyzmu w Polsce. Na dalszy rozwój, upowszechnienie i utrwalenie takiego "stylu" przeżywania religii wpływ miał oczywiście długoletni pontyfikat Jana Pawła II (1978-2005) i religijne uroczystości gromadzące pod gołym niebem tłumy uczestników podczas dziewięciu wizyt papieża w Polsce. Swego rodzaju zwieńczeniem takiej formy wspólnotowej celebracji były zgromadzenia modlitewne, tworzone na wpół spontanicznie po śmierci Jana Pawła II w kwietniu 2005 roku. To wówczas, na zakończenie tzw. Białego Marszu, na krakowskie Błonia dotarł ponad milion osób. Sama „masowość” jest zatem w polskim kontekście religijnym zjawiskiem raczej oswojonym, przywołującym dobrze znane formy zachowań, często poruszające głębokie emocje i transformacyjne zbiorowe oraz indywidualne doświadczenia. Wydawać by się mogło, że nie powinna być czymś z góry określanym mianem problematycznego, czy wręcz wartościowana negatywnie.

Po wtóre, w związku z tym, że Światowe Dni Młodzieży są organizowane przez Kościół katolicki, można przypuszczać, że stopień identyfikacji z nimi jako „naszym wydarzeniem" powinien być w sporej mierze paralelny ze stopniem identyfikacji z katolicyzmem. Chociaż według statystyk społeczeństwo polskie jest deklaratywnie wysoce katolickie $(87,58 \%)$, sytuacja na poziomie gruntu jest dużo bardziej skomplikowana, a głębsze analizy socjologiczne oraz antropologiczne wskazują na olbrzymią i stale rosnącą dywersyfikację postaw wobec instytucji Kościoła katolickiego, wyobrażeń na temat „polskiego katolicyzmu” czy stosunku do udziału w praktykach religijnych'. Jak sądzę, konfrontacja ze Światowymi Dniami Młodzieży, z którymi zmierzyli się mieszkańcy Krakowa - w dużej mierze wszak statystyczni katolicy - świetnie ujawniła ową wieloznaczność i różnorodność relacji pomiędzy „polskimi katolikami” a „katolicyzmem”"

Etnograficzne wywiady prowadzone z krakowianami na temat zbliżających się, a potem także trwających w mieście Światowych Dni Młodzieży niejednokrotnie przemieniały się $\mathrm{w}$ długie (nawet kilkugodzinne) rozmowy o osobistym

8 W miejscu tym nawiązuję do rozumienia „stylu” w ujęciu Birgit Meyer, która podkreśla wagę podzielanych zachowań oraz wrażliwości estetycznych i czuciowych w procesach formowania wspólnot religijnych. Zob. Meyer (2009: 10-11).

9 W spisie powszechnym w 2011 roku 87,58\% społeczeństwa zadeklarowało przynależność do katolicyzmu. Z kolei publikowane przez Instytut Statystyki Kościoła Katolickiego dane wskazują na spadek katolików biorących udział w podstawowych praktykach religijnych. W 2016 roku uczestnictwo w niedzielnych mszach świętych określono na $36,7 \%$, a communicantes stanowią $16 \%$ w obrębie grupy tzw. katolików zobowiązanych (do tej grupy nie zalicza się dzieci do 7 roku życia oraz osób wiekowych), zob. Praktyki niedzielne Polaków...

10 Wśród naszych rozmówców oprócz osób na różne sposoby związanych z rzymskim katolicyzmem, które zdecydowanie dominowały, znaleźli się grekokatolicy (zaangażowani w ŚDM) oraz protestanci. Rozmawialiśmy również z osobami deklarującymi się jako ateiści lub agnostycy (choć w tej grupie dominowało definiowanie się w relacji do katolicyzmu poprzez jego porzucenie). W niniejszym artykule jedynie sygnalizuję temat konfrontacji indywidualnych i zbiorowych tożsamości religijnych Polaków z globalnym katolickim wydarzeniem, jakim były ŚDM. Pracę nad tym tematem obecnie kontynuuję. 
stosunku do katolicyzmu oraz do chrześcijaństwa i innych religii, zagadnień tożsamości religijnych we współczesnym świecie czy obecności religii w prywatnym życiu, a także jej widoczności w przestrzeni publicznej. Ludzie obserwowali bowiem nie tylko ŚDM i przygotowania do nich, ale również swoje reakcje i emocjonalne responsy na to wydarzenie (pozytywne, jak i negatywne), co w dużej mierze skłaniało do refleksji na tematy szerzej związane z religią, jej rolą w przestrzeni publicznej oraz swoją własną tożsamością religijną. Można zaryzykować stwierdzenie, że ambiwalentny, niejednoznaczny, często zniuansowany, ale też selektywny w ocenach stosunek do ŚDM - który dominował w materiale etnograficznym zebranym wśród krakowian (niektóre elementy postrzegane pozytywnie, przy równoczesnym wskazywaniu negatywnie wartościowanych aspektów wydarzenia; selektywne zwracanie uwagi na wymiar uznawany przez daną osobę za ważny i subiektywnie znaczący) - odpowiadał podobnie niejednoznacznym oraz zdywersyfikowanym postawom wobec Kościoła katolickiego (a często „religii” w ogóle). Wydaje się zatem, iż założenie o paralelności postaw wobec Kościoła katolickiego oraz ogólnej oceny ŚDM jest w dużej mierze zasadne, choć oczywiście niepozbawione uproszczeń i interpretacyjnych pułapek.

Faktycznie, w zebranym materiale można zauważyć, że osoby deklarujące się jako "głęboko wierzące” oraz "praktykujący katolicy” miały z reguły ogólnie pozytywny stosunek do ŚDM, podczas gdy rozmówcy „zdecydowanie niereligijni” najczęściej wyrażali spory dystans do „imprezy organizowanej przez Watykan w Krakowie bez zgody, bez pytania krakowian o zgodę" albo wprost jej krytykę. Ale nawet w tych najbardziej skrajnie usytuowanych deklaratywnych grupach trudno pokusić się o uogólnienia. Zdarzali się np. wierzący katolicy krytykujący „masowość” ŚDM czy ich zbyt „lekki”, „imprezowy” charakter. Z kolei w grupie, którą można określić jako „zdecydowanie niewierzący”, były osoby okazujące entuzjazm wobec wielokulturowego wymiaru wydarzenia (takie reakcje pojawiły się zwłaszcza po przyjeździe pielgrzymów i rozpoczęciu ŚDM, kiedy panująca w mieście atmosfera radosnego spotkania nierzadko udzielała się pobocznym obserwatorom, także tym wobec ŚDM sceptycznym - często ku ich wielkiemu zaskoczeniu, o czym wspominali w rozmowach, na portalach społecznościowych, forach internetowych itd.). Wyjątkowy do tej pory w kontekście polskim globalny wymiar spotkania ${ }^{11}$, jego ogrom i masowość, ale też specyficzny - religijno-festiwalowy charakter - wywoływały wśród mieszkańców Krakowa różne emocjonalne reakcje, wymagające często konfrontacji z dotychczasowymi wyobrażeniami na temat „katolicyzmu” i własnymi odniesieniami tożsamościowymi.

11 Można zwrócić uwagę na międzynarodowy wymiar Euro 2012 - to sportowe wydarzenie miało jednak charakter kontynentalny, podczas gdy ŚDM 2016 przyciągnęły ludzi z całego świata. 


\section{Między eventem a pielgrzymką}

Jak zauważyła Michaela Pfadenhauer, niemiecka badaczka, która analizowała sposoby organizacji i prezentacji Światowych Dni Młodzieży w 2005 roku w Kolonii, cała struktura tego wydarzenia odpowiada innym, podobnym megaeventom stanowiącym ważny element współczesnej kultury popularnej (2010). Przyjęta dziś forma ŚDM ukształtowała się w ciągu pierwszej dekady ich historii i jest nadzorowana z Watykanu przez Papieską Radę do spraw Świeckich, z którą każdorazowo ściśle współpracują organizatorzy krajowi (Halter 2013: 278). Światowe Dni Młodzieży odbywają się co kilka lat (2-3). Uczestnicy wydarzenia przybywają na jeden tydzień do określonej lokalizacji, gdzie spędzają czas zgodnie z ustalonym bardzo intensywnym programem, którego schemat zasadniczo powtarza się podczas wszystkich ŚDM. Program tygodnia porządkują tzw. wydarzenia centralne, takie jak: „ceremonia otwarcia”, polowe nabożeństwa i msze święte z kulminacyjną „mszą posłania”, która jest poprzedzona całonocnym czuwaniem $^{12}$. Podczas tego ostatniego wydarzenia głowa Kościoła katolickiego papież, który jest też głównym celebransem mszy - uroczyście ogłasza datę i miejsce kolejnego globalnego „spotkania młodych”.

Niewątpliwie Światowe Dni Młodzieży można określić mianem eventu, który zgodnie ze strategią Kościoła katolickiego, marketingowo „otwartego na nowe formy życia społecznego", promuje wiarę jako swego rodzaju „produkt” (zob. Pfadenhauer 2010). Co ciekawe, podobnie jak duże festiwale muzyczne czy olbrzymie wydarzenia sportowe (olimpiada, mistrzostwa świata, kontynentalne turnieje futbolowe) Światowe Dni Młodzieży stały się też same w sobie produktem (opatrzonym marką ŚDM) - właśnie poprzez już uformowaną schematyczność, powtarzalność zasadniczych elementów, kojarzoną z nimi „atmosferę”, która za każdym razem powinna być podobnie intensywna, związana $\mathrm{z}$ wyobrażeniami „młodości” i różnorodności międzykulturowego religijnego spotkania. Podobnie jak inne cykliczne megaeventy ŚDM mają każdorazowo swoje logo, hasło, hymn oraz szereg innych reprezentacji wspierających ich promocję, widoczność i rozpoznawalność (spoty reklamowe, postacie „ambasadorów”, gadżety itd.).

Frapującym zagadnieniem jest nieobecność w oficjalnej nazwie wydarzenia jakichkolwiek odniesień do religijnego czy wręcz konfesyjnego charakteru Światowych Dni Młodzieży. Wydaje się, że to właśnie "globalność” i „młodość” mają stanowić hasła przyciągające tych, którym słowa „religia” lub „katolicyzm” nie kojarzą się najlepiej ${ }^{13}$. Na kwestię tę - pozornie paradoksalną, biorąc pod uwagę

12 Oprócz wydarzeń centralnych czas wypełniają rozmaite spotkania modlitewne (m.in. katechezy), kulturalne i edukacyjne prowadzone w grupach. Ponadto uczestnicy ŚDM korzystali z bogatej oferty turystycznej i kulturalnej przygotowanej przez miasto, muzea, rozmaite instytucje regionalne i kościelne.

13 Jest to istotne zwłaszcza w kontekście tych społeczeństw, w których wizerunek Kościoła katolickiego został mocno nadszarpnięty przez informacje o rozmaitych skandalach z udziałem insty- 
wskazany wcześniej fakt, że ŚDM z założenia mają służyć promocji katolicyzmu - zwracali uwagę niektórzy nasi rozmówcy (zwłaszcza nieidentyfikujący się z katolicyzmem i mający negatywny stosunek do ŚDM). Ich komentarze były zbliżone do tych wygłoszonych przez jednego $z$ lewicowych australijskich polityków podczas debaty parlamentarnej nad przyjęciem specjalnej ustawy przed ŚDM 2008 w Sydney, który w przyjętym nazewnictwie widział rodzaj zawoalowanej „działalności marketingowej Kościoła katolickiego” (Halter 2013: 275). Z kolei, jak wykazały badania strategii organizacyjnych i hermeneutyczna interpretacja materiałów promocyjnych przed ŚDM 2005 w Kolonii, mimo deklarowanej przez watykańską Radę do spraw Świeckich otwartości na odmienne wyznania i religie czy też osoby niereligijne, finalnie w praktyce grupę docelową, do której trafiali lokalni organizatorzy, stanowili niemal wyłącznie „młodzi ludzie, którzy mieli już za sobą proces kościelnej socjalizacji” (Pfadenhauer 2010: 388). Przekaz informacyjny oraz większość praktyk organizacyjnych posiadały bowiem mocny rys konfesyjnej wyłączności, który nie zachęcał „niekatolików” do udziału w wydarzeniu (promowanie wydarzenia poprzez odwołania do katolickich symboli i hierarchii, system rejestracji dostępny przez katolickie parafie etc.) ani go im nie ułatwiał.

Zatem mimo braku konfesyjnych odwołań w nazwie Światowe Dni Młodzieży są jednoznacznie kojarzone z Kościołem katolickim. Zarówno wyeksponowanie "młodości” i „globalności”, jak i nadanie ŚDM formatu typowego megaeventu odsłaniają pewną dwutorowość czy wręcz paradoksalność strategii przyjętej przez organizatorów, która bezpośrednio przekłada się na wielowymiarowy, niejednoznaczny charakter tego wydarzenia. Światowe Dni Młodzieży zaprojektowane są jako nowoczesne, atrakcyjne dla różnych młodych ludzi wydarzenie z kręgu kultury popularnej, posługujące się globalnym językiem tejże kultury i nawiązujące bardzo mocno do uniwersalności doświadczeń ludzkich, a w szczególności do uniwersalności doświadczeń ludzi młodych, którzy na całym świecie „są tacy sami". Równocześnie jest to wydarzenie stricte religijne, związane z konkretnym chrześcijańskim wyznaniem, posługujące się bardzo mocno tradycyjnymi katolickimi mediami religijnymi (np. drewniany krzyż i ikona Matki Boskiej Salus Populi Romani jako „symbole ŚDM”), liturgią i przywołujące hierarchiczną strukturę Kościoła katolickiego. Fenomen ŚDM polega właśnie na tym, że jednocześnie „jest to megaimpreza oraz religijne święto" (Pfadenhauer 2010: 391).

Australijscy religioznawcy, analizując ŚDM 2008 w Sydney, zwrócili uwagę na podkreślanie przez organizatorów religijnego charakteru wydarzenia poprzez aplikowanie do niego kategorii pielgrzymki (Norman, Johnson 2011). Badania Alexa Normana i Marka Johnsona niewątpliwie ukazują jeden z dyskursów, który, jak sądzę, jest przede wszystkim adresowany do aktywnych uczestników ŚDM. Badacze zwrócili m.in. uwagę na rzucającą się w oczy nieobecność słowa "turysta” na stronie internetowej ŚDM 2008, podobnie jak i w innych materiałach przygo-

tucji bądź jej przedstawicieli (m.in. związanych z molestowaniem seksualnym nieletnich). Na temat kontekstu australijskiego zob. np. prace Nicholasa Haltera (2013: 269). 
towanych przez organizatorów. Mowa była wyłącznie o „pielgrzymach” udających się na „pielgrzymkę”, mimo wyraźnie obecnych typowo „turystycznych” elementów. W ten sposób „organizatorzy pragną oddzielić doświadczenie ŚDM od semantycznych skojarzeń związanych z turystyką festiwalową - nie chcą, aby ŚDM były postrzegane jako wydarzenie «niepoważne»" (Norman, Johnson 2011: 379).

Należy zauważyć, że współczesne, antropologicznie zorientowane badania nad religią głęboko sproblematyzowały kategorię „pielgrzymki” i „pielgrzymowania” (więcej na ten temat zob. Niedźwiedź 2016, 2017b). Dziś wielu badaczy, zwłaszcza tych, których teoretyczne zaplecze jest ugruntowane w doświadczeniu etnograficznych badań terenowych, z olbrzymią ostrożnością podchodzi do dychotomicznego rozumienia takich kategorii jak „pielgrzym” i „turysta”, ale też sacrum i profanum, religijny i świecki, duchowość i marketing (zob. np. Eade, Sallnow 1991; Coleman, Eade 2004; Collins-Kreiner 2010; Reader 2014). W zamian podkreślają kulturowe, płynne i kontekstualne znaczenia tych terminów oraz wieloaspektowość, paradoksalność i różnorodność semantyczną ludzkich praktyk i doświadczeń. ŚDM mogą stanowić dobry przykład takiego właśnie kompleksowego, pełnego współwystępujących sprzeczności, polifonicznego wydarzenia, w którym trudno jednoznacznie wskazać, co jest sacrum, a co profanum.

Przeformułowanie antropologicznej teorii nie oznacza jednak oczywiście zniknięcia czy osłabienia obecności binarnie zorientowanych porządków w dyskursach kulturowych. Przykładowo, jedna z podstawowych narracji stworzona przez organizatorów i promotorów ŚDM, mocno eksponowana w przebiegu tego wydarzenia oraz wyrastająca z papieskiego nauczania zwłaszcza podczas pontyfikatów Jana Pawła II i Benedykta XVI, odwołuje się do wyraźnie opozycyjnego zestawienia „świętości” (wiązanej z przestrzenią chrześcijańskiego zgromadzenia) z „sekularyzacją” współczesnego, otaczającego młodych ludzi świata (zob. Norman, Johnson 2011: 373-340). W kontekście takiej narracji kreowanie obrazu ŚDM jako „współczesnej pielgrzymki” sugeruje zdecydowaną jakościową odmienność Światowych Dni Młodzieży od strukturalnie podobnych „laickich”, konsumpcyjnie i rozrywkowo zorientowanych wydarzeń. Na pierwszej stronie Modlitewnika - niewielkiej żółtej książeczki, którą jako element „pakietu pielgrzyma” otrzymywali wszyscy zarejestrowani uczestnicy ŚDM w Krakowie - przeczytać można, że rozpoczynające się właśnie wydarzenie, „chociaż zewnętrznie podobne jest do innych wielkich spotkań i festiwali, tak popularnych dzisiaj wśród ludzi młodych, to jednak jego prawdziwy sens i znaczenie odkryjemy dopiero wtedy, gdy zagłębimy się w duchowe przeżycia, które ono niesie" (Modlitewnik 2016: 5) Zatem także krakowskie Dni Młodzieży zostały przedstawione ich uczestnikom przede wszystkim jako pielgrzymka, rozumiana jako religijna podróż, dziejąca się w miejscu i czasie „świętym”, rytuał przynoszący szczególne doświadczenie spotkania i zawiązania wspólnoty między ludźmi oraz pomiędzy zgromadzonymi a sacrum. Istotną rolę w kreacji opowieści o ŚDM 2016 jako „religijnej pielgrzymce” odegrała lokalna scenografia wydarzenia - przestrzeń miasta Krakowa i związane z nią postacie świętych. 


\section{„Miasto Świętych"}

Jak to jest, wszędzie jest Jan Paweł II, a gdzie Franciszek na mieście?,

Wiszą te obrazki wzdłuż całych Alej [Trzech Wieszczów]. A dlaczego tam nie ma Franciszka? Na każdej latarni Jan Paweł II i Faustyna!,

To trochę śmiesznie by było, gdyby gdzieś przyjechała głowa państwa, jedzie z lotniska, a tu wszędzie witają go flagi z wizerunkami zmarłego poprzednika - a jak widać, Franciszka w Krakowie będzie witał Jan Paweł II.

W tych i wielu innych podobnych wypowiedziach krakowianie komentowali wizualne reprezentacje zbliżającego się wydarzenia, które pod koniec czerwca wkroczyły w przestrzeń miasta i których z każdym tygodniem przybywało. Tramwaje i autobusy pokryły się hasłami i twarzami znanych osób promujących oraz zapowiadających ŚDM, na ulicach i placach pojawiły się plakaty i stelaże z banerami, ustawiono maszty z flagami w kolorach przywołujących logotyp wydarzenia, a wzdłuż najważniejszych i najbardziej ruchliwych arterii komunikacyjnych wywieszono kolorowe, utrzymane w stylistyce logotypu wizerunki oficjalnych patronów spotkania: Świętych siostry Faustyny i Jana Pawła II. To właśnie te czerwono-żółto-niebieskie twarze Faustyny i Jana Pawła II szczególnie przyciągały uwagę i stały się przedmiotem licznych komentarzy, nierzadko krytycznych. Duża liczba mocno wyeksponowanych reprezentacji Jana Pawła II, przy skromnej wizualnej obecności papieża Franciszka w materiałach promujących wydarzenie w przestrzeni miasta, została momentalnie zauważona przez mieszkańców i temat ten bardzo często pojawiał się w prowadzonych przez nas rozmowach. Przy okazji niektórzy wspominali odczytywany miesiąc wcześniej w katolickich kościołach list duszpasterski „zapraszający na ŚDM” i fakt - wytknięty publicznie przez publicystę Adama Szostkiewicza - pominięcia w nim milczeniem obecnego papieża, przy trzykrotnym przywołaniu Jana Pawła II (Polscy biskupi zapraszaja... 2016; zob. także Szostkiewicz 2016).

Szczególnie intensywne powoływanie się na Jana Pawła II i włączenie jego wizerunku w strategię marketingową ŚDM 2016 mogą być poniekąd zrozumiałe, gdyż to właśnie ten papież był inicjatorem pierwszego wydarzenia w 1985 roku i jako głowa Kościoła katolickiego brał udział w kolejnych Dniach Młodzieży (aż do ŚDM 2002 w Toronto), wpływając na ich kształt i wpisując się w ich historię. Kanonizacja Jana Pawła II (2014), rozwój kultu, powiązanie jego postaci z ideą miłosierdzia Bożego uczyniły go idealnym kandydatem na patrona ŚDM (obok św. s. Faustyny Kowalskiej) w okresie obchodzonym przez Kościół katolicki jako „rok miłosierdzia”. Niewątpliwie wskazanie Krakowa jako gospodarza ŚDM 2016 było swego rodzaju hołdem dla „polskiego papieża”. To właśnie Kraków - co najmniej od czasu śmierci Jana Pawła II - jest bowiem postrzegany i promowany jako „miasto papieskie” i centrum jego kultu. 
W innych publikacjach analizowałam procesy i zabiegi (instytucjonalne oraz oddolne), które doprowadziły do włączenia osoby Jana Pawła II w przestrzeń miasta, czyniąc go jednym z elementów „lokalnego dziedzictwa” (zob. np. Niedźwiedź 2017a, 2017c). Tutaj warto przypomnieć, że Jan Paweł II jest postrzegany jako „współczesny święty”, stanowiący najnowsze wcielenie sięgającej średniowiecza narracji o „krakowskich świętych” - postaciach pobożnych chrześcijan wywodzących się z miasta lub z nim związanych. W dzisiejszym Krakowie można wędrować „szlakiem krakowskich świętych” oraz splatającymi się z nim „ścieżkami Jana Pawła II”, zwiedzić „najstarszy polski uniwersytet”, „w którym studiował późniejszy papież Jan Paweł II”, odbyć pielgrzymkę „Śladami Karola Wojtyły robotnika”, nawiedzić dedykowane mu nowiutkie monumentalne sanktuarium, pomodlić się przy „oryginalnej płycie z grobu papieża” przywiezionej do Krakowa z Grot Watykańskich, ucałować jego relikwie, zobaczyć zbroczoną krwią sutannę, którą miał na sobie w dniu zamachu w 1981 roku, przystanąć pod „oknem papieskim”, odwiedzić pokoje, w których zamieszkiwał jako student, ksiądz czy biskup, a nawet obejrzeć helikopter, którym wożono go podczas papieskich wizyt w Polsce... ${ }^{14}$

Związek krakowskiej przestrzeni z postacią Jana Pawła II oraz innych „krakowskich świętych" stał się kluczowym elementem lokalnej scenografii, która nie tylko towarzyszyła, ale również współtworzyła ŚDM 2016. Przestrzeń miasta stała się bowiem nie tyle areną dla globalnego wydarzenia, ile jego integralnym elementem, wpływającym na formę spotkań i celebracji oraz doświadczenia uczestników. To właśnie postacie „krakowskich świętych” - z Janem Pawłem II oraz siostrą Faustyną na czele - oraz związane z nimi krakowskie loci sacra, integralnie włączone w program ŚDM 2016, pozwoliły uczestnikom na przeżycie tego wydarzenia jako „pielgrzymki”, która w swoim tradycyjnym rozumieniu w kontekście chrześcijańskim oznacza transformacyjną wędrówkę do przestrzeni świętej, np. sanktuarium, i doświadczenie tam spotkania z sacrum, często poprzez materialne medium relikwii, wizerunku itd. Zaaranżowana jako obowiązkowy punkt programu dla wszystkich zarejestrowanych uczestników „Pielgrzymka Miłosierdzia” (obejmująca wizytę w sanktuarium św. Jana Pawła II i przejście do sanktuarium Bożego Miłosierdzia w Łagiewnikach) oraz projekt „Miasto Świętych” (realizowany w trzynastu kościołach związanych z kultem poszczególnych „krakowskich świętych") uruchomiły przestrzeń miasta i włączyły jego scenografię w formowanie przeżyć i zachowań pielgrzymów.

Szczególnie interesujący był projekt „Miasto Świętych”, który opierał się na fizycznym i duchowym naśladowaniu konkretnych praktyk związanych z postacią świętego, w konkretnym miejscu „szczególnie z nim związanym” (zob. Przewodnik pielgrzyma ŚDM 2016: 86). W ten sposób przestrzeń miejska, wyposa-

14 O muzealizacji postaci Jana Pawła II oraz roli wybranych eksponatów/obiektów/relikwii „papieskich” w procesie wpisywania JPII w przestrzeń Krakowa oraz w wyobrażenie „krakowskiego dziedzictwa” pisze m.in. Bartosz Arkuszewski w swoim artykule opublikowanym w tym numerze „Prac Etnograficznych”. 
żona w szereg „autentycznych loci sacra” - związanych z jakąś realnie istniejącą postacią świętego (co było mocno podkreślane) - pozwalała pielgrzymom na głębokie i ucieleśnione doświadczenie spotkania z sacrum. Przykładowo w ramach projektu „Miasto Świętych” młodzi pielgrzymi byli zachęcani do wyspowiadania się w bazylice Mariackiej, gdzie „do dzisiaj stoi konfesjonał, w którym w latach 50. XX w. ks. Karol Wojtyła regularnie spowiadał" (88), czy do pomodlenia się w katedrze wawelskiej dokładnie „w tym samym miejscu, w którym modliła się św. Jadwiga” (92). Podczas gdy analizy ŚDM 2008 ukazywały brak „sakralnego potencjału" w przestrzeni Sydney i wynikającą z tego problematyczność kategorii „pielgrzymki”, którą zbudowano tam wokół postaci papieża-celebryty - głowy Kościoła i żywego uczestnika zdarzeń (zob. Norman, Johnson 2011: 380) - przykład Krakowa wskazuje na odmienną sytuację i związaną z nią strategię polegającą na uruchomieniu religijnego wymiaru przestrzeni miejskiej oraz związanego z nią obrazu „chrześcijańskiego dziedzictwa”. Kraków jest ukazany jako „miasto wielu świętych i błogosławionych” (Muskus 2016: 4), a „wszyscy ci święci żyli w Krakowie w różnych okresach ponadtysiącletniej historii chrześcijaństwa w Polsce” (Przewodnik pielgrzyma 2016: 86). Podobne odwołania do „dziedzictwa chrześcijańskiego" i zaangażowanie lokalnej scenografii w budowanie doświadczenia ŚDM jako pielgrzymki można też wskazać w wypadku Santiago de Compostela (1989 rok), Rzymu (2000 rok) czy Kolonii (2005 rok). W tym ostatnim miejscu mocno eksponowano katedrę oraz jej związek z postaciami Trzech Króli - pierwszych „chrześcijańskich pielgrzymów”. Ukazywani na ich wzór uczestnicy ŚDM mieli przybywać do miasta z różnych stron świata, by tak samo jak oni „oddać pokłon" Jezusowi (zob. Pfadenhauer 2010: 386-387).

\section{Uwagi końcowe}

Światowe Dni Młodzieży to wieloaspektowy „fenomen kulturowo-religijny” (Kieca, Kleska 2017), który każdorazowo uruchamia rozmaite lokalne oraz narodowe dyskursy i zestawia je z perspektywami globalnymi i transnarodowymi. Sprzyja temu masowość wydarzenia, związana z nim podróż głowy Kościoła katolickiego do kraju-gospodarza, swego rodzaju rozpoznawalna „marka” ŚDM jako cyklicznego eventu o zasięgu światowym, zaangażowanie w organizację niemałych nakładów finansowych (w tym także ze środków publicznych) oraz olbrzymie zainteresowanie mediów. ŚDM stają się obiektem wielorakich publicznie wygłaszanych komentarzy, ale też instrumentalizacji oraz form ich upolityczniania. Bywają narzędziem prowadzenia polityki nie tylko dla Kościoła katolickiego, ale również dla lokalnych rządów państw przyjmujących czy innych społecznych instytucji oraz podmiotów. W tym miejscu chciałam jedynie zasygnalizować to zagadnienie, wracając raz jeszcze do postaci papieża Franciszka i jego reprezentacji. Wydaje się bowiem, że zauważony przez krakowian „nadmiar” wizualnych przedsta- 
wień Jana Pawła II (choć ideowo uzasadniany związkami świętego z Krakowem i historią ŚDM) wiąże się z szerszą dyskusją na temat "polskiego konserwatyzmu” zestawianego z bardziej „liberalnym” nurtem w Kościele, z którym kojarzony jest papież Franciszek, co funkcjonuje również na poziomie odniesień politycznych.

W zebranym materiale etnograficznym postać papieża Franciszka była często łączona $\mathrm{z}$ „kwestią uchodźców” i „ekologią”. Pierwsze z tych zagadnień pojawiało się zresztą podczas oficjalnych wystąpień papieża w Polsce, także tych skierowanych do władz państwowych wyrażających odmienne od watykańskiego stanowisko. Nieprzypadkowo wkrótce po zakończeniu ŚDM w różnych miejscach miasta można było zobaczyć naklejki organizacji pozarządowych wspierających pomoc dla uchodźców opatrzone cytatem $\mathrm{z}$ wypowiedzi papieża i jego wizerunkiem. Z kolei gdy rok później, podczas obrad komitetu UNESCO w Krakowie, demonstrowano „w obronie Puszczy Białowieskiej”, na transparentach ekologów również pojawiła się twarz obecnego papieża. Franciszek staje się w polskim kontekście swego rodzaju kulturową ikoną - uosobieniem określonych postaw społecznych. Właśnie dlatego skromna obecność jego przedstawień w oficjalnym wystroju miasta podczas ŚDM była tematem wielu gorących komentarzy wśród krakowian. Doszło nawet do oddolnej obywatelskiej interwencji. Tuż przed rozpoczęciem ŚDM na Rynku Głównym, wśród flag z portretami Jana Pawła II i Faustyny, pojawił się również papież Franciszek - wymalowany przez dwie studentki krakowskiej Akademii Sztuk Pięknych, w takiej samej jak portrety patronów wydarzenia trójbarwnej kolorystyce. Ta swoista społeczno-polityczna manifestacja polegająca na „nielegalnym” powieszeniu baneru z papieżem Franciszkiem w samym sercu miasta została odebrana przez niektórych jako moment symbolicznego przywrócenia mieszkańcom sprawczości - oddania im głosu poprzez zmianę scenografii, w której Światowe Dni Młodzieży miały się odbywać.

W krótkim artykule nie sposób poruszyć wszystkich aspektów tak skomplikowanego wydarzenia, jakim każdorazowo są Światowe Dni Młodzieży i jakim były również te zorganizowane w Krakowie w lipcu 2016 roku. Podsumowując, warto zwrócić uwagę nie tylko na niejednorodność oplecionych wokół wydarzenia i tworzących je dyskursów, ale również ujawniającą się niekiedy ich paradoksalność czy wręcz nieprzystawalność oraz rozmaite instrumentalizacje. Zakładam, że wielogłosowość narracji, polityk oraz doświadczeń świetnie mieści się w specyfice Światowych Dni Młodzieży, które są wydarzeniem masowym, a zarazem przeżywanym przez uczestników w sposób bardzo osobisty, podkreślającym wspólnotowość i jedność, ale także różnorodność katolicyzmu i tworzących go katolików, hierarchię instytucji Kościoła i egalitaryzm religijnej wspólnoty, intensywną duchowość podzielanej tradycji religijnej i co najmniej równie intensywną ludyczność wielokulturowego młodzieżowego spotkania. Są równocześnie globalne i lokalne - gromadzą ludzi z całego świata i odwołują się do światowych problemów, a z drugiej strony mocno ingerują w życie lokalnej społeczności, która na rozmaite sposoby pozycjonuje się wobec tego wydarzenia. 


\section{Bibliografia}

Bilska-Wodecka E., Sołjan I., Liro J., 2017 Motivations of Participants of World Youth Day in Krakow (2016), [w:] Proceeding of the 10 ${ }^{\text {th }}$ MAC 2017 (Multidiciplinary Academic Conference), Prague, s. 204-206.

Bobako M., 2017 Islamofobia jako technologia władzy. Studium z antropologii politycznej, Kraków.

Coleman S., Eade J., 2004 Introduction: Reframing Pilgrimage, [w:] Reframing Pilgrimage: Cultures in Motion, eds. S. Coleman, J. Eade, London-New York, s. 1-25.

Collins-Kreiner N., 2010 Researching Pilgrimage: Continuity and Transformations, „Annals of Tourism Research", 37 (2), s. 440-456.

Eade J., Sallnow M.J. (eds.), 1991 Contesting the Sacred: The Anthropology of Christian Pilgrimage, London-New York.

Halter N.,

2013 The Australian Catholic Church and the Public Sphere: World Youth Day 2008, "Journal of Religious History”, vol. 37, no. 2, s. 261-282.

Kieca M., Kleska Ł.,

2017 Światowe Dni Młodzieży. Fenomen kulturowo-religijny, Warszawa.

Kościót prosi o pomoc: przyjmijcie ludzi!

2016, portal KRK news.pl, 7 lipca, http://krknews.pl/kosciol-prosi-o-pomoc-przyjmijcie-pielgrzymow/ (dostęp: 04.01.2018).

Lambek M.,

2013 What Is „Religion” for Anthropology? And What Has Anthropology Brought to „Religion"?, [w:] A Companion to the Anthropology of Religion, eds. J. Boddy, M. Lambek, Chichester, s. 1-32.

Meyer B.,

2009 Introduction. From Imagined Communities to Aesthetic Formations: Religious Mediations, Sensational Forms, and Styles of Binding, [w:] Aesthetic Formations: Media, Religion, and the Senses, ed. B. Meyer, New York, s. 1-28.

Modlitewnik, ŚDM

2016 Kraków.

Muskus D., 2016 Drodzy młodzi Przyjaciele!, [w:] Przewodnik Pielgrzyma ŚDM, Kraków, s. 4-5.

Niedźwiedź A., 2016 Skrzyżowane itineraria - antropolodzy i pielgrzymi, „Prace Etnograficzne”, t. 44, z. 3, s. 243-260.

2017a Framing the Pope within the Urban Space: John Paul II and the Cityscape of Kraków, [w:] Spiritualizing the City: Agency and Resilience of the Urban and Urbanesque Habitat, eds. V. Hegner, P.J. Margry, London-New York, s. 81-101.

2017b Migoczaca mapa - w stronę antropologii pielgrzymowania, „Konteksty, Polska Sztuka Ludowa”, LXXI, nr 1-2, s. 191-203.

2017c The Multivocality of Space and the Creation of Heritages: New Shrines in an Old City, „Anthropological Notebooks”, vol. 23, nr 3, s. 63-86. 
Norman A., Johnson M.,

2011 World Youth Day: The Creation of a Modern Pilgrimage Even for Evangelical Intent, „Journal of Contemporary Religion”, 26, 3, s. 371-385.

Pfadenhauer M.,

2010 The Eventization of Faith as a Marketing Strategy: World Youth Day as an Innovative Response of the Catholic Church to Pluralization, "International Journal of Nonprofit and Voluntary Sector Marketing", vol. 15, November, s. 382-394.

Polscy biskupi zapraszają na Światowe Dni Młodzieży

2016 Kościelna Agencja Informacyjna, List duszpasterski odczytany w kościołach 19 czerwca, https://ekai.pl/wydarzenia/x100651/polscy-biskupi-zapraszaja-na-swiatowe-dni-mlodziezy/?print=1 (dostęp: 4.07.2016).

Praktyki niedzielne Polaków (dominicantes i communicantes), Instytut Statystyki Kościoła Katolickiego, http://iskk.pl/badania/religijnosc/211-praktyki-niedzielne-polakow-dominicantes (dostęp: 8.01.2018).

Przewodnik pielgrzyma ŚDM

2016, Kraków.

„Podczas ŚDM w Krakowie może być ciężko. Zachęcam do wyjechania na zielona trawkę”. Zapis rozmowy Jacka Bańki z prezydentem Krakowa Jackiem Majchrowskim

2016 Radio Kraków, 19 lutego, http://www.radiokrakow.pl/rozmowy/j-majchrowski-podczas-sdm-w-krakowie-moze-byc-ciezko-zachecam-do-wyjechania-na-zielona-trawke/ (dostęp: 22.12.2017).

Reader I.,

2014 Pilgrimage in the Marketplace, New York-London.

Sadłoń W. (oprac.),

2016 Etapy socjalizacji religijnej i elementy postaw religijnych uczestników Światowych Dni Młodzieży w 2016 r., Warszawa.

Sadłoń W., Werner M., 2016 Wprowadzenie, [w:] Odbiór Światowych Dni Młodzieży i jego kulturowe konteksty. Raport z badania uczestników Światowych Dni Młodzieży Kraków 2016, Warszawa.

Szostkiewicz A.,

2016 ŚDM, czy czegoś nie wiemy?, https://szostkiewicz.blog.polityka.pl/2016/06/19/ sdm-czy-czegos-nie-wiemy/ (dostęp: 22.12.2017).

Szpunar O., Gurgul A.,

2016 Wynająłeś swoje mieszkanie podczas ŚDM? To zarobiłeś!, „Gazeta w Krakowie”, 10 sierpnia; http://krakow.wyborcza.pl/krakow/1,44425,20524035, wynajales-apartament-podczas-sdm-to-zarobiles.html\#BoxLokKrakLink (dostęp: 10.08.2016).

ŚDM 2016. „Kraków będzie przestrzenia duchowego rozwoju”. Ks. Grzegorz Suchodolski o przygotowaniach i programie Światowych Dni Młodzieży Kraków 2016 2015 Polskie Radio (Sygnały dnia/Jedynka), 22 sierpnia, https://www.polskieradio. pl/7/129/Artykul/1492268,SDM-2016-Krakow-bedzie-przestrzenia-duchowego-rozwoju (dostęp: 22.12.2017). 


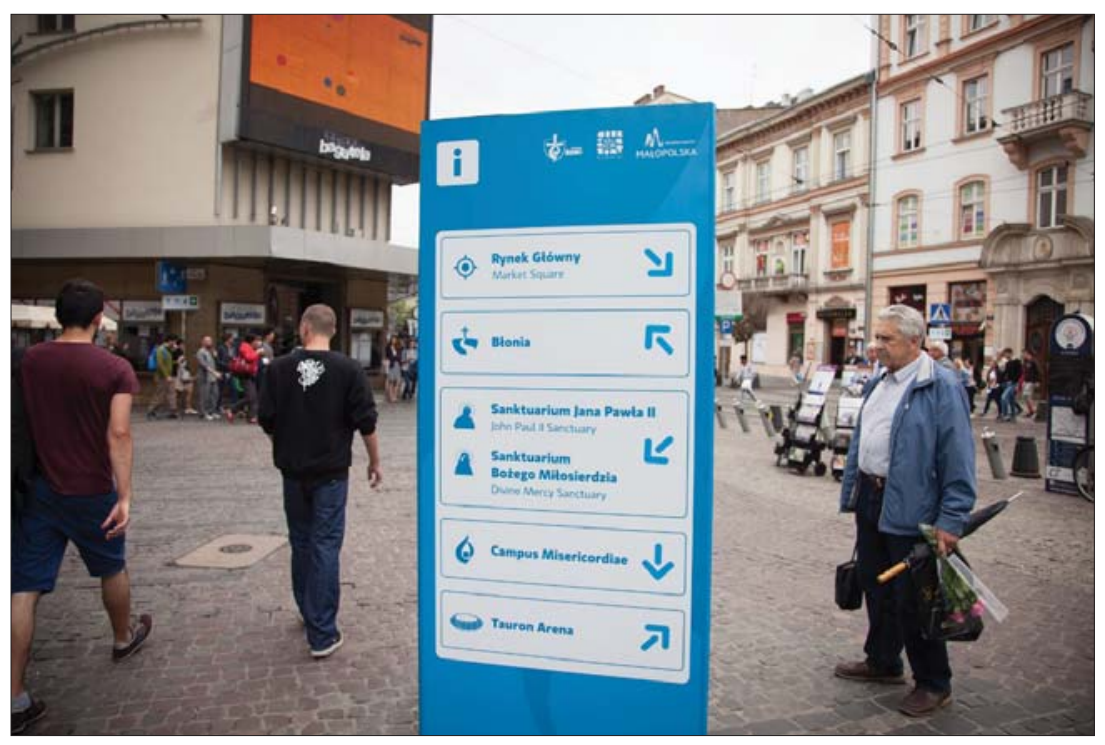

Fot. 1. Przechodnie obserwujący tablice informacyjne ŚDM, które pojawiły się na terenie miasta tydzień przed rozpoczęciem wydarzenia. Fot. Marcin Wąsik

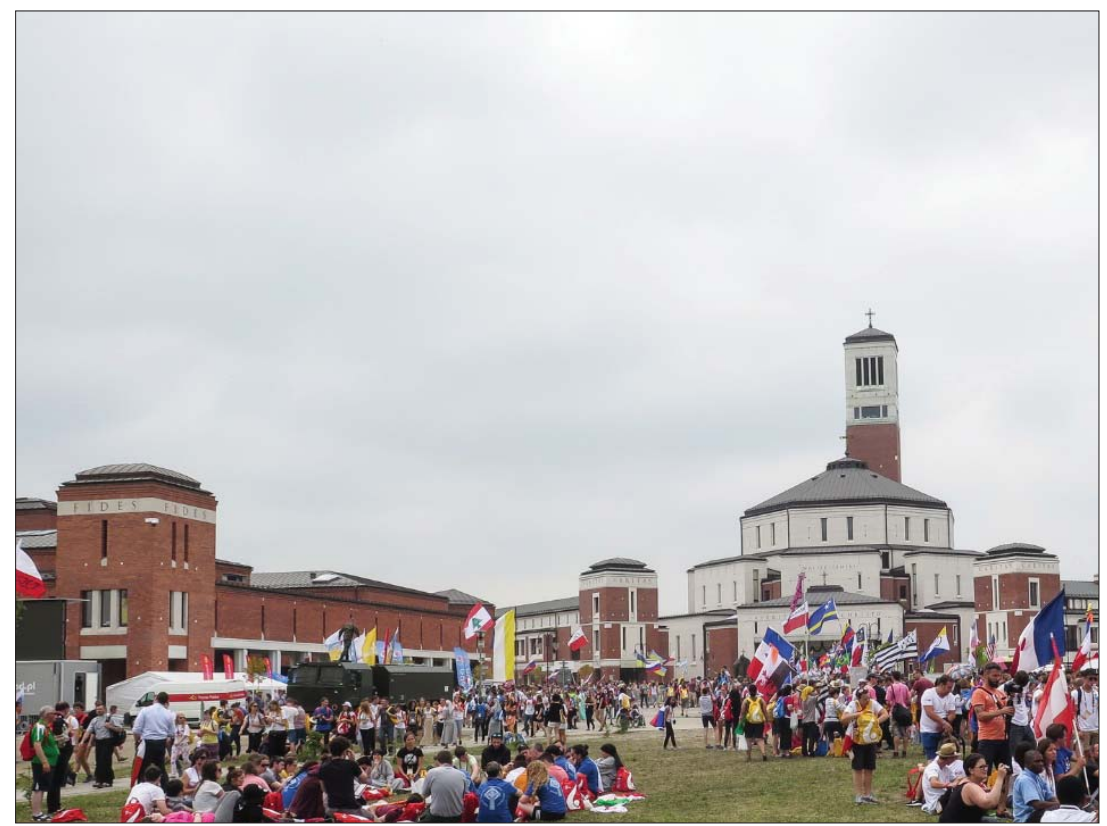

Fot. 2. Uczestnicy Światowych Dni Młodzieży przed sanktuarium św. Jana Pawła II w Krakowie. Fot. Marcin Wąsik 


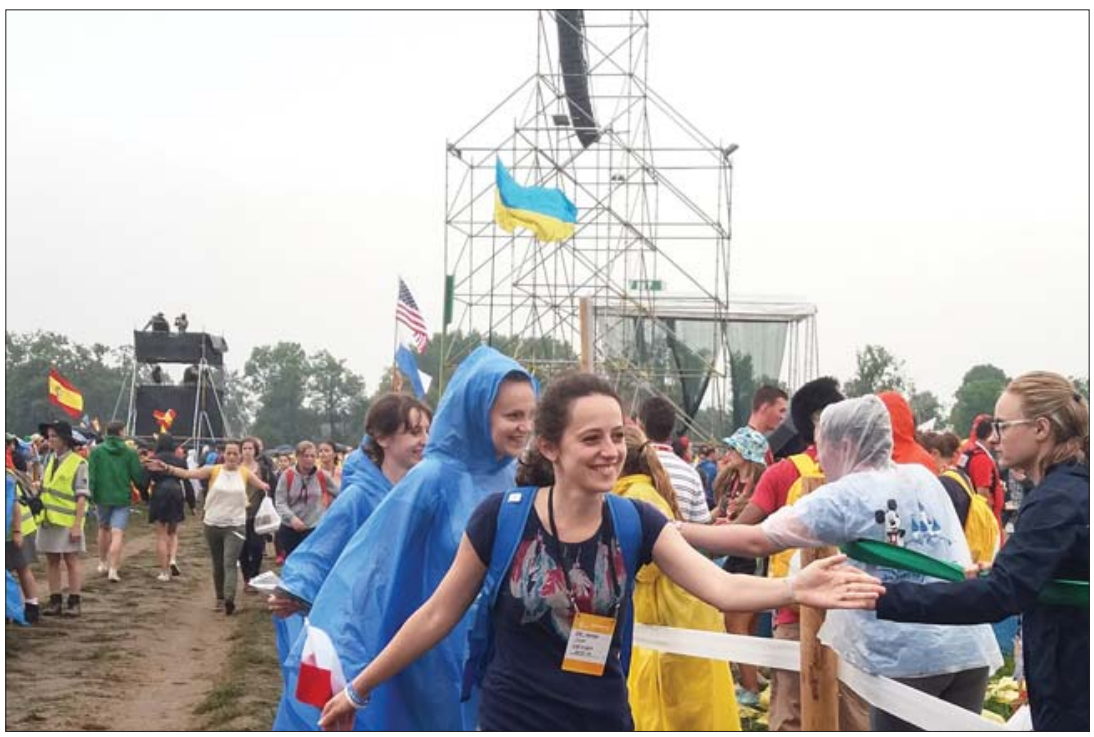

Fot. 3. Na Błoniach przed spotkaniem z papieżem Franciszkiem, 28 lipca 2016. Fot. Marcin Wąsik

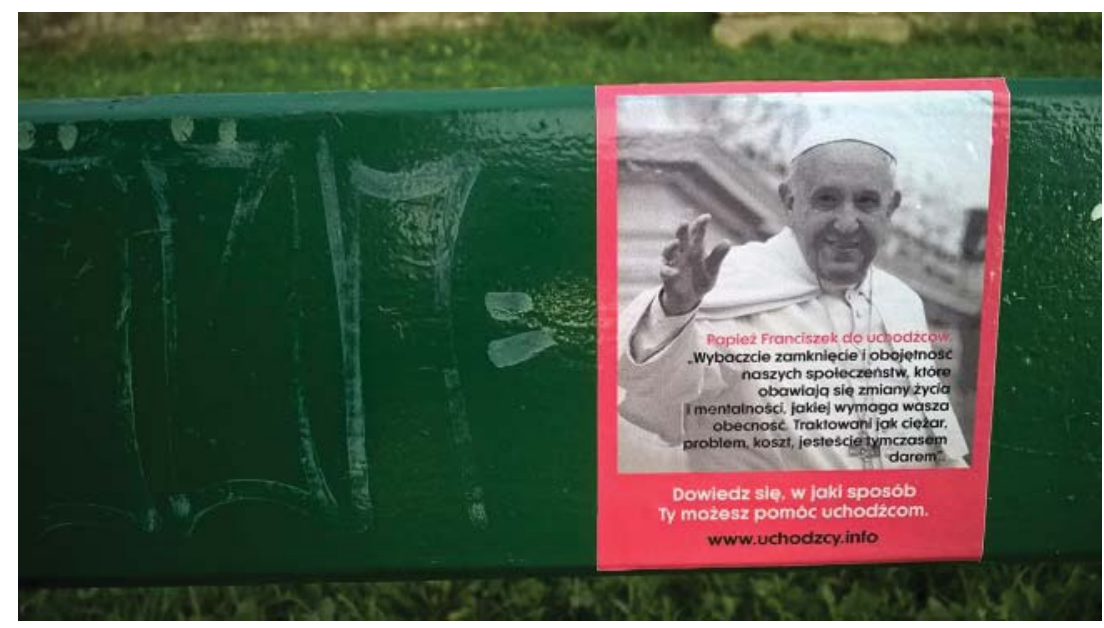

Fot. 4. Naklejka umieszczona na ławce nad Wisłą, sierpień 2016. Fot. Anna Niedźwiedź 


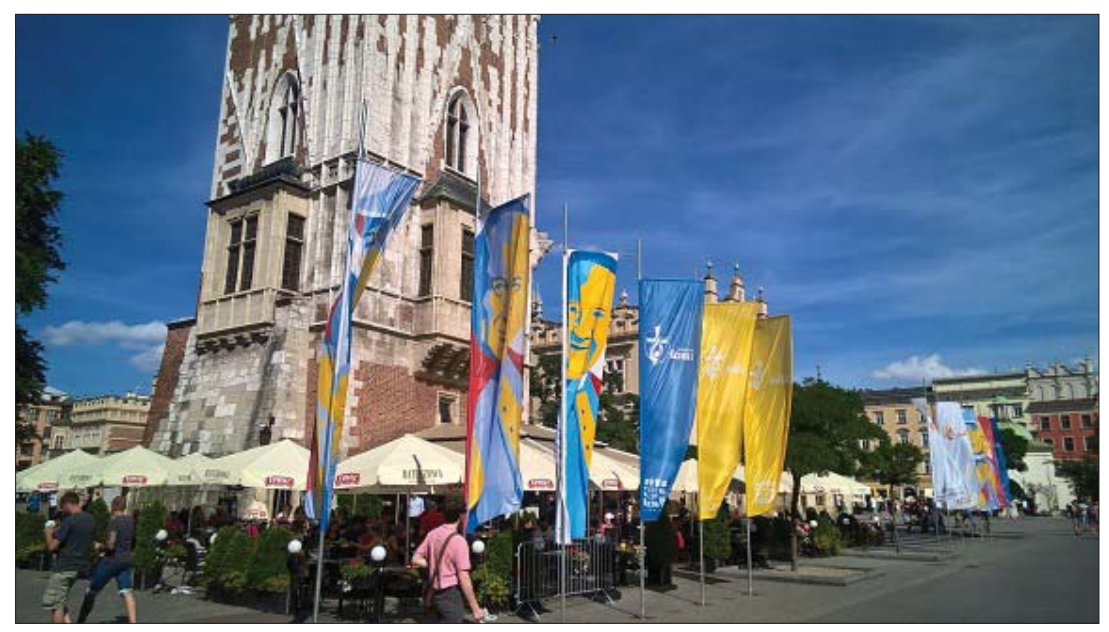

Fot. 5. Flaga z twarzą papieża Franciszka zawieszona przez studentki krakowskiej ASP - Marię Olbrychtowicz i Janę Shostak - obok oficjalnych banerów wydarzenia i flag z twarzami Jana Pawła II oraz siostry Faustyny. Fot. Anna Niedźwiedź 